\title{
Banking Governance and Risk: The Case of Tunisian Conventional Banks
}

\author{
Houssem Rachdi, ${ }^{1}$ Mohamed Ali Trabelsi, ${ }^{2}$ Naama Trad ${ }^{3}$
}

\begin{abstract}
Banks are in the business of taking risks. The 3 pillars of Basel II capital accord highlight the crucial role of informative risk disclosures in enhancing market discipline. The specific role and responsibilities of the board of directors or supervisory boards in banking institutions continue, however, to fuel debate. Findings of the literature are often inconclusive. The main contribution of this study is examining how board characteristics affect risk in banking industry. We explore this relationship by using many econometric approaches. The empirical analysis based on a sample of 11 Tunisian conventional banks over the period 2001-2011 reports the following results when using GLS RE: small and dual functions boards are associated with more insolvency risk but have no significant effect on credit and global risks. The presence of independent directors within the board generates an increase in global risk but has no significant effect on insolvency and credit risks. A lower CEO ownership has no significant effect with all measures of risks. Finally, banking capitalization is associated with more insolvency risk, and small size banks assume lower credit risk. These findings are performed by using a GMM in system approach.
\end{abstract}

Key words: Board characteristics, Bank risk, Governance, GLS RE, GMM system

JEL Classification: G30, G32, G34

\section{Introduction}

The international financial crisis which hit world economy in 2007 and has intensified since mid-September 2008 has been marketed as the most serious crisis that has ever occurred after the 1929 Great Depression (Trabelsi, 2011). Although the crisis initiated with the American subprime market bubble, it has progressively spread to most international financial markets through derived products. The global nature of the crisis is its most distinctive feature in that most countries were affected. Subprime credits are purely an American practice (they exist under more or less moderated forms in other countries like the UK) and it is the American institutions which are known for loans. This crisis has nevertheless quickly expanded due to an interdependence characterizing financial institutions, securitization which allowed investors access to foreign real estate markets and to re-evaluation of risk price. Decrease in risky assets prices in the US affected European banks which possessed such assets, thus reducing their demand and speeding European stock markets collapse.

\footnotetext{
${ }^{1}$ Faculty of Law, Economics and Management of Jendouba, University of Jendouba, Tunisia. rachdih@uvic.ca

${ }^{2}$ High Business School of Tunis, University of Manouba, Tunisia. daly1704@yahoo.fr

${ }^{3}$ High Business School of Tunis, University of Manouba, Tunisia. tradnaama@yahoo.fr
} 
The emergence of this crisis and the recession that followed, as well as the dispersion of public trust in organizations management has raised several questions on bank governance and the role of banks in this event (Manière, 2012). In this context, Hasan et al. (2009) concluded that the start of these crises which were followed by an economic downturn relates to bank governance quality system. Indeed, several researchers, including Beck et al. (2000), Wurgler (2000) and Caprio et al. (2007) concluded that banking system stability leads to the proper functioning of the financial system, which in turn promotes economic growth. Therefore, it is imperative to implement reforms and corrective actions that will allow the financial system to become more efficient and stable. This is the reason that led regulators to conduct a discussion on both the methods of crisis resolution and the imposition of new prudential standards, and therefore setting healthier and stronger bank governance (Borisova et al., 2012; Manière, 2012).

Different governance mechanisms may consist of main banking risk factors. Dannon (2009) states that the internal mechanisms of governance and ownership structure contribute to improving bank governance and are therefore more effective in explaining bank risk. Risk mitigation and performance improvement remain a major competitive opportunity and a competitive advantage. Since the publication of Berle and Means's (1932) book "The modern corporation and private property", conflicts between shareholders and managers have been a subject of numerous studies which aimed at integrating within company's operation diagram, the nature of the objectives pursued by the leaders and whether they differ from those of shareholders (Williamson, 1963).

To explain interest differences between managers and shareholders, Jensen and Meckling (1976) suggest three reasons. The first source of conflict stems from the fact that investors' perception of risks is different to that of executives. The second source is rooted in horizon differences between shareholders and managers. Finally, the third is represented by the collection of policy benefits in kind by managers at the expense of shareholder interests. According to Jensen and Meckling, these conflicts generate what these authors call agency costs. However, market imperfections and the presence of some criteria, such as the theory of transaction costs and information asymmetry; require an intervention of bank governance to address these problems. Therefore, governance system of banks is based on some pillars: regulation, external mechanisms and internal mechanisms. In addition, the financial literature has always considered ownership structure as a primary mechanism to resolve governance interest conflicts between managers and shareholders and can enhance firm value. Based on these headlines, previous studies dealing with the relationship between board characteristics and risk-taking led to conflicting results in the United States of America and Europe.

Few scientific papers deal with the relationship between banking governance and risk taking. The aim of our study is to examine the nature of the relationship between governance internal mechanisms and management of banking risks in the Tunisian context. The main contribution of this paper lies in the fact that it allows to test the contribution of governance from the perspective of internal mechanisms in explaining bank risk, and also to study the impact of board characteristics on risks of Tunisian commercial banks. The paper is structured as follows: The second section presents a review of the literature relevant to the relationship between board characteristics and risk-taking. The third section describes the data, variables selected, econometric approaches and the main empirical results. The fourth section concludes the paper. 


\section{Literature Review, Theory and Hypotheses Development}

The separation between ownership and control has meant that the law gave wide powers to the board of directors. Fama and Jensen (1983) show the importance of the board in the control structure, mainly in large companies. Indeed, for them, the board should be an incentive and a disciplinary mechanism for managers to resolve agency conflicts and maximize firm value.

Referring to the Principle 1 of Basel recommendations on bank governance (2006), "Board members should be qualified for their positions, have a clear understanding of their role in corporate governance and be able to exercise sound judgment about the affairs of the bank". The identification of the board of directors' relevance to risk taking is determined by its size, its management and its structure (Jezzini, 2005 \& Bliss et al. 2007). The work of Adams and Mehran (2003) on U.S. banks shows the existence of a positive relationship between performance and banks with multi-member boards of directors.

Chia-Ling (2011) shows that the CEO/chairperson duality is associated with lower corporate performance. The CEO and chairperson is the same person, a fact which leads to insufficient monitoring of the board, resulting in a reduced performance. He also shows that more independent directors in the board are required when the CEO/ chairperson duality exists. Based on this analysis, three hypotheses are developed to examine risk management in relation to governance mechanisms.

\subsection{Impact of Board Size on Bank Risk-taking}

Studies on the relationship between the board of director's size and banking risks generated conflicting results. Rachdi and Ghazouani (2011) found a negative and statistically significant relationship between a small board and insolvency risk in Tunisia, which is consistent with the work of Andres and Vallelado (2008) and Pathan (2009). According to these authors, and in line with the recommendations of the code of good corporate governance in Tunisia, a small number of directors within the board accelerates decision making and facilitates control contrary to large boards that make the communication process more cumbersome and difficult, and may face coordination problems due to their supervision efforts (Lipton and Lorsh, 1992). Moreover, Trabelsi (2010) shows that a large number of members within the Board has a very negative effect on performance of Tunisian banks. In this context, Jensen (1993) argues that effective control of sales is lost when the size of board of directors is large.

Other studies (Brokovich et al., 2004, Ben Khediri, 2006, and Dannon, 2009) question the effectiveness of board of directors in reducing risk when it is small, and on a basis of arguments show the presence of a positive relationship between small size and banking risk. They believe that a large board of directors could help better assess the risk of investment projects thanks to a diversified structure and to a better expertise. Then, the larger the number of directors, the lower banking risks. Salloum and Azoury (2008), who point out, confirm this result that an increase in size of the board in the case of financially insolvent firms seems necessary and is as an effective mechanism. Similarly, Blanchard and Dionne (2003) suggested that the use of sophisticated instruments to hedge risk increase with an increase of the number of directors constituting the board. 
For these authors, the boards have a wider control power and adequate information sources and they tend to undertake risk-hedging activities.

Thus, the formal representation of the first hypothesis of this study is as follows: Hypothesis1. (H1): board size has an effect on Bank risk-taking

\subsection{Impact of CEO Duality on Bank Risk-taking}

The relationship between the chairman function and the role of leadership was raised by agency theory. Jensen (1993) shows negative effects of the chairman/chairwoman on risky investments when he or she holds the position of a CEO. Trabelsi (2010) confirms this association in Tunisian banks. For the control function to be effective, it is recommended that the general manager does not occupy the position of chairman.

In Tunisia and according to the note issued on 2012 by the governor of the Central Bank on good governance rules, it is recommended that the principle of separation between decision and control functions in the reforms be introduced in 2012 in order to establish a sound and prudent management ensuring sustainability of banks. In the same context, Mamoghli and Dhouibi (2009) have shown empirically that the risk of insolvency of Tunisian banks increases if the manager also occupies the function of the chairman. Dannon (2009) found out that the dual functions of director and chairman of the board led to risky credit and investment decisions because in the case of a dual leadership, the manager may have higher authority on the board and the entire banking firm, which may result in a reduction of the effectiveness of controls. Likewise, empirical studies found a negative effect of this combination of functions on the risk of firms' bankruptcy (Daily and Dalton, 1993).

Based on these arguments, the second hypothesis of this study is as follows:

Hypothesis2. (H2): Duality of the general manager has an effect on Bank risk-taking

\subsection{Impact of Independent Directors on Bank Risk-taking}

Several studies examined the effect of the presence of external directors on bank. Agency theory suggests that outside directors play an important role in monitoring managers' performance. Jensen (1993) and Pathan (2009) found that a significant percentage of external directors serving on the board contribute to a strong reduction of various banking risks (total risk, risk of asset returns, idiosyncratic risk, systematic risk and insolvency risk). Similarly, Lefort and Urzua (2008), Dahya et al. (2008) and Lin et al. (2010) agree that the presence of outsiders on the board maximize shareholder wealth and ensure sustainability of the firm because of their skills on the one hand and their experience serving the benefits of the company. In this context, Ben Khediri (2006) believes that boards with a significant proportion of external directors, risk coverage probability is high. Blanchard and Dionne (2003) argued that "the more important the number of external directors is the more important hedging activities". In response to this argument, a second line of thought suggests that external directors are not able to determine function control of managers, and their presence on the board is not desirable because they have no effect on the decision to hedge risk and are unable to effectively monitor management of executives (Dionne and Triki, 2005). This can be explained by the fact that they are unable to understand the specificities of the bank (opacity, 
complexity... $)^{4}$ and they cannot take advantage of their knowledge which may be useful to reduce risk in contrast to internal directors who are more informed about the different activities and specificities of their business (Linck et al., 2008).

Based on these arguments, the third hypothesis of this study is as follows:

Hypothesis3. (H3): independent directors has an effect on Bank risk-taking

\section{Empirical Framework}

\subsection{Sampling Procedure and Composition}

The sample examined in this paper consists of the 11 largest domestic commercial banks in Tunisia over the period 2001-2011, totaling 121 observations. The data are sourced of Tunis Stock Exchange. Annual reports of the selected banks and completed form are of the Bankscope database. Following Adams and Mehran (2008), the governance data are measured on the date of the proxy statement, i.e., at the beginning of the respective fiscal year.

\subsection{Empirical Model and Measures of Variables}

The increased interest in banks' board governance following the recent international financial crisis motivates us to investigate whether and to what extent their board structure affects risks. Our aim is to examine the following relationship, and we will refer to the study of Pathan (2009) conducted in American banks. This regression equation is constructed to test empirically the three main hypotheses, H1, H2 and H3, given the theoretical and empirical discussion in Section 2.

$$
\begin{gathered}
\operatorname{Risk}_{i, t}=\alpha+\beta_{1} \operatorname{Ln}(B S)_{i t}+\beta_{2} D{ }^{2} L_{i t}+\beta_{3} I N D_{i t}+\beta_{4} C E O W N_{i t}+ \\
\beta_{5} \operatorname{Ln}(B \mathrm{ANKS})_{i t}+\beta_{6} C A P_{i t}+\varepsilon_{i t}
\end{gathered}
$$

Where subscripts $i$ denotes individual banks $(\mathrm{i}=1,2, \ldots ., 11), \mathrm{t}$ time period $(\mathrm{t}=2001,2002, \ldots, 2011), \mathrm{Ln}$ is the natural logarithmic, $\beta$ are the parameters to be estimated and $\varepsilon$ is the error term. Risk: Several different measures of bank risk-taking have been used in empirical studies. In this study, we measure bank risk taking using the Z-score, the credit risk and the global risk of each bank. Z-score equals the return on assets (ROA) plus the capital asset ratio divided by the standard deviation of asset returns. Because the z-score is highly skewed, we use the natural logarithm of the $\mathrm{z}$ score, which is normally distributed. The credit risk equals customers credits divided on customers' deposits. The global risk equals the standard deviation of the return on assets. Board size (BS): is the total number of directors serving on the bank board at the end of each fiscal year. Duality of the general manager (DUAL): is a dummy variable that equals one if the CEO also chairs the board, but is otherwise zero. Independent directors (IND): is the number of independent directors, as a percentage of the total number of board directors.CEO ownership (CEOWN): The percentage of the banks CEO's

\footnotetext{
${ }^{4}$ Fore more detail, see Becht et al. (2011). Why bank governance is different. Oxford Review of
} Economic Policy, 27, 437-463. 
shareholdings. Bank size (BANKS): Total assets as at the end of each fiscal year. Capital (CAP): Total equities as at the end of each fiscal year.

\subsection{Econometric Analysis}

Like Pathan (2009), we estimate the equation using a within estimator (Fixed effect) and a generalized least square random effect (GLS RE), following the Baltagi and Wu (1999) technique. Table 1 presents regressions of the impact of bank board determinants on risk when either Z-score, credit risk and global risk are the dependent variable.

The Hausman test confirms the appropriateness of the random-based effects estimation procedure used in this study (P-value of Hausman statistics is larger than 5\%).Also, the fixed estimator is inconsistent in our study because this procedure aggravates the problem of multicolinearity due the existence of dummy variable (Duality of the general manager). Using the GLS RE, the regression is well-fitted with an overall R squared of $40.8 \%$ for Z-score, $29.6 \%$ for credit risk and $25.8 \%$ for global risk with statistically significant Wald Chi-square $\chi^{2}$ statistics for all risk measures.

The coefficient on BS is negative across all risk measures $(-0.563$ for Z-score, -0.751 for credit risk and -0.003 for global risk) and only statistically significant at the level of $1 \%$ for Z-score. This result illustrates that banks with small board are associated with more insolvency risk (Andres andVallelado2008; Pathan (2009; Rachdi and Ghazouani 2011). For the variable BANKS, the coefficient is negative across all measures of risk (0.412 for Z-score, -6.446 for credit risk and -0.002 for global risk), and only statistically significant at the level of $1 \%$ for credit risk. This implies that small size banks institutions assume lower credit risk. Bouaiss (2008) find a significant negative relationship between risk and the size of the bank.

This table presents the results of GLS RE estimator. Z-score, credit risk and global risk are the dependant variables. Board size (BS), duality of the general manager (DUAL), independent directors (IND), CEO ownership (CEOWN), Bank size (BANKS) and Capital (CAP) are the independent variables. The reported t-statistics with GLS RE estimates are robust to random fixed-effect and to heteroskedasticity. Hausman $\chi^{2}$ statistics: The test evaluates the significance of an estimator versus an alternative estimator. Wald $\chi^{2}$ statistics: The test is a way of testing the significance of particular independent variables in a statistical model. The numbers in parentheses represent the absolute values of t-statistics.

Turning our attention to the variable CEOWN, we find out that coefficients are positive (1.368 for Z-score, 6.011 for credit risk, and 0.013 for global risk) and not significant across all risk measures. Our findings about the not statistically significant positive coefficient on CEOWN across risk point to clear evidence that indicates that as the percentage of CEOs shareholdings increases, their risk preference decreases. This result is not consistent with findings of Pathan (2009) for US banks. Consistent with expectation, coefficients associated to IND are positive (1.232 for Z-score, 9.746 for credit risk and 0.131 for global risk) and only statistically significant for the former at $10 \%$ level for global risk because independent boards are more sensitive to regulatory compliance. Lefort and Urzua (2008) and Lin et al. (2010) find that the presence of outside directors enhance returns of shareholders and reduce the risk taking. In contrast, Pathan (2009) finds a negative and statistically significant result for total risk in US 
banks. The coefficients on DUAL (1.164 for Z-score, 2.795 for credit risk and 0.008 for global risk) and CAP (8.511 for Z-score, 6.483 for credit risk and 0.026 for global risk) are still positive and statistically significant across the Z-score.

Table 1: Regression Results of the Bank Board Structure and Alternative Measures of Risk

\begin{tabular}{|c|c|c|c|}
\hline Variables & $\begin{array}{c}\text { Z-SCORE } \\
\text { GLS RE }\end{array}$ & $\begin{array}{c}\text { Credit risk } \\
\text { GLS RE }\end{array}$ & $\begin{array}{c}\text { Global risk } \\
\text { GLS RE }\end{array}$ \\
\hline BS & $\begin{array}{c}-0.563 * * * \\
(2.69)\end{array}$ & $\begin{array}{l}-0.751 \\
(0.98)\end{array}$ & $\begin{array}{l}-0.003 \\
(0.93)\end{array}$ \\
\hline DUAL & $\begin{array}{c}1.164 * * \\
(2.27)\end{array}$ & $\begin{array}{l}2.795 \\
(1.45)\end{array}$ & $\begin{array}{l}0.008 \\
(1.13)\end{array}$ \\
\hline IND & $\begin{array}{l}1.232 \\
(0.38)\end{array}$ & $\begin{array}{l}9.746 \\
(0.88)\end{array}$ & $\begin{array}{c}0.131 \\
(1.65)^{*}\end{array}$ \\
\hline CEOWN & $\begin{array}{l}1.368 \\
(0.79)\end{array}$ & $\begin{array}{l}6.011 \\
(0.92)\end{array}$ & $\begin{array}{l}0.013 \\
(0.47)\end{array}$ \\
\hline BANKS & $\begin{array}{l}-0.412 \\
(0.83)\end{array}$ & $\begin{array}{c}-6.446 * * * \\
(3.74)\end{array}$ & $\begin{array}{l}-0.002 \\
(0.28)\end{array}$ \\
\hline CAP & $\begin{array}{c}8.511 * * * \\
(5.94)\end{array}$ & $\begin{array}{l}6.483 \\
(1.16)\end{array}$ & $\begin{array}{l}0.026 \\
(1.23)\end{array}$ \\
\hline Constant & $\begin{array}{c}-14.531 \\
(1.24)\end{array}$ & $\begin{array}{c}12.162 * * * \\
(3.29)\end{array}$ & $\begin{array}{l}0.172 \\
(0.84)\end{array}$ \\
\hline Number of Observation & 113 & 121 & 117 \\
\hline Wald $\chi^{2}$ Statistics & 78.42 & 34.64 & 35.42 \\
\hline P-value of Wald $\chi 2$ & 0.000 & 0.000 & 0.000 \\
\hline Within $\mathrm{R}^{2}$ & 0.435 & 0.273 & 0.226 \\
\hline Between $\mathrm{R}^{2}$ & 0.355 & 0.094 & 0.300 \\
\hline Overall $\mathrm{R}^{2}$ & 0.408 & 0.296 & 0.258 \\
\hline Rho & 0.260 & 0.565 & 0.479 \\
\hline Hausman $\chi^{2}$ statistics & 3.30 & 12.79 & 2.88 \\
\hline P-value Hausman & 0.771 & 0.246 & 0.823 \\
\hline
\end{tabular}

\subsection{Robustness Test: Dynamic Panel GMM in System Estimation}

For robustness tests, we estimate the same regression using Generalized Method of Moments in system (GMM in system). In table 2, according to Wintoki et al. (2012), the GMM in system estimator has been used to explore findings of GLS RE. We will use one lag of the instrumental variable to limit the potential problem with more weak instruments. 
Table 2: Regression Results of the Bank Board Structure and Alternative Measures of Risk

GMM in system

\begin{tabular}{|l|c|c|c|}
\hline Variables & $\begin{array}{c}\text { Z-SCORE } \\
\text { GMM }\end{array}$ & $\begin{array}{c}\text { Credit risk } \\
\text { GMM }\end{array}$ & $\begin{array}{c}\text { Global risk } \\
\text { GMM }\end{array}$ \\
\hline BS & $\begin{array}{c}-0.242 \\
(0.74)\end{array}$ & $\begin{array}{c}-0.221 \\
(0.23)\end{array}$ & $\begin{array}{c}-0.002 \\
(0.77)\end{array}$ \\
\hline DUAL & 0.042 & 0.115 & 0.000 \\
& $(0.16)$ & $(0.44)$ & $(0.03)$ \\
\hline IND & -5.579 & 3.813 & 0.097 \\
& $(1.07)$ & $(0.39)$ & $(0.22)$ \\
\hline CEOWN & 0.200 & -8.393 & -0.018 \\
\hline BANKS & $(1.33)$ & $(0.10)$ & $(0.90)$ \\
\hline CAP & 0.216 & $-2.145 * * *$ & -0.004 \\
& $(1.15)$ & $(4.32)$ & $(0.38)$ \\
\hline Constant & $9.186 * * *$ & 0.952 & 0.003 \\
& $(4.67)$ & $(0.32)$ & $(0.15)$ \\
\hline Number of Observation & 31.490 & $-50.438 * * *$ & 0.109 \\
\hline Wald $\chi^{2}$ Statistics & $(0.94)$ & $(2.66)$ & $(0.44)$ \\
\hline P-value of Wald $\chi^{2}$ & 100 & 110 & 103 \\
\hline Sargan Test & 3465.39 & $1.07 \mathrm{e}+06$ & 13.23 \\
\hline P-valueSargan & 3.550 & 3.276 & 5.021 \\
\hline AR (1) & 1.000 & 1.000 & 1.000 \\
\hline P-value AR $(1)$ & -0.979 & -1.078 & -1.628 \\
\hline AR $(2)$ & 0.327 & 0.280 & 0.103 \\
\hline P-value AR $(2)$ & -0.952 & -0.990 & 0.664 \\
\hline$* * *$ and *** indicate statistical & 0.341 & 0.321 & 0.506 \\
\hline significance at the $1 \%, 5 \%$, and & $10 \%$ levels \\
\hline
\end{tabular}

This table presents the results of a GMM in system estimator. Z-score, credit risk and global risk are the dependant variables. Board size (BS), duality of the general manager (DUAL), independent directors (IND), CEO ownership (CEOWN), Bank size (BANKS) and Capital (CAP) are the independent variables. The reported t-statistics with GLS RE estimates are robust to random fixed-effect and also to heteroskedasticity. AR (1): Arellano and Bond test of null of zero first-order serial correlation, distributed $\mathrm{N}(0,1)$ under null. AR (2): Arellano and Bond test of null of zero second-order serial correlation, distributed N $(0,1)$ under null. Sargan test: Is a statistical test used to check for over-identifying restrictions in a statistical model.Wald $\chi^{2}$ statistics: The test is a 
way of testing the significance of particular independent variables in a statistical model. The numbers in parentheses are the absolute values of t-statistics.

The Wald-test indicates fine goodness of fit, the Sargan and serial-correlation tests do not reject the null hypothesis of correct specification (P-value of Sargan test and P-value of AR (2) test of Arellano and Bond are larger than 5\%), lending support to our estimation results.

For the Z-score, the reported coefficients estimates are similar to the results issued from GLS RE except for IND and BANKS. Contrary to our expectation, the coefficient on IND is negative (-5.579) and not statistically significant. This result is similar to findings of Pathan (2009) who found a negative and not statistically significant coefficient between independent directors and insolvency risk. The coefficient of BANKS is positive $(0.216)$ and not statistically significant. This implies that small size banks assume lower insolvency risk.

For credit risk, the reported coefficients estimates are similar to the results issued from GLS RE except for CEOWN and for the global risk the reported coefficients estimates are similar to the results issued from GLS RE except for CEOWN. Our findings about the statistically non-significant negative coefficient on CEOWN across credit risk point to a clear evidence, which indicates that as the percentage of CEOs shareholdings decreases, credit risk preference increases.

\section{Conclusion and Policy Implications}

This paper tried to assess whether bank board structure (board size, composition, CEO ownership and CEO duality) is associated with risks. Using a sample of 11 Tunisian conventional banks over the 2001-2011 period, this paper finds evidence which indicates that a small bank board and duality board are associated with more insolvency risk but have no significant effect with credit and global risks. The presence of independent directors within the board of directors generates an increase of global risk but has no significant effect on insolvency and credit risks. A lower CEO ownership has no significant effect in the three measures of risks. Bank capitalization is associated with more insolvency risk and small size banks assume lower credit risk.

The results of this study imply that bank board characteristics are a crucial factor of bank risk-taking. Those findings have potential policy implications for regulators of Tunisian banks: to maintain a performing banking stream, Tunisia should strengthen rules and practices of mechanisms of banking governance because poor governance in financial institutions generates significant costs for all the economy, and good practices are appropriate for promoting well-functioning banks. Since 2011, the Central Bank of Tunisia has been working to enhance the role of the board of directors in banking governance and to empower the monitoring of Tunisian banks. The board should determine global risk tolerance level and translate it into different risk categories and develop a strategy that respects the interests of all stakeholders. Also, Tunisia must adopt the Financial Stability Board (FSB) recommendations and establish audit, nominating, and compensation committees composed entirely of independent directors to strength internal and external risks. 


\section{Acknowledgments}

Authors acknowledge the editor and the reviewers of the Review of Economic Perspectives for useful comments. Suggestions of reviewers may help in better perception of the paper by potential readers.

\section{References}

ADAMS R.B. MEHRAN H., (2003). Board Structure, Banking Firm Performance and The Bank Holding Company Organizational Form, Federal Reserve Bank of Chicago Proceedings, pp. 408-422.

ADAMS, R.B. MEHRAN, H., (2008). Corporate performance, board structure and their determinants in the banking industry. Working Paper, Federal Reserve Bank of New York.

ANDRES P.D. VALLELADO, E., (2008). Corporate Governance in Banking: The Role of the Board of directors, Journal of Banking and Finance, pp. 4-32.

BALTAGI, B.H. WU, P.X., (1999). Unequally spaced panel data regressions with AR(1) disturbances. Econometric Theory 15, pp. 814-823.

BASEL COMMITTEE ON BANKING SUPERVISION (2006). Enhancing Corporate Governance for Banking Organizations.

BECHT, M. BOLTON, P. ROELL, A. (2011). Why bank governance is different. Oxford Review of Economic Policy, 27, pp. 437-463. DOI: 10.1093/oxrep/grr024

BECK T., LEVINE R. LOAYZA N., (2000). Financial Intermediation and Growth: Causality and Causes, Journal of Monetary Economics, 46(1), pp. 31-77. DOI: $\underline{10.1016 / \mathrm{S} 0304-3932(00) 00017-9}$

BEN KHEDIRI K., ( 2006). Gouvernance d'Entreprise et Couverture des Risques Financiers: étude empirique sur les entreprises Françaises, CIME, IAE de Caen, pp. 126.

BERLE A.A. MEANS G.C., (1932). The Modern Corporation and Private Property, MacMillan Company, New York.

BLANCHARD D., DIONNE G., (2003). Risk Management and Corporate Governance, Working Paper, pp. 3-4

BLISS M.A., MUNIANDY B. MAJID A., (2007). CEO Duality, Audit Committee Effectiveness and Audit Risks, Managerial Auditing Journal, 22 (7), pp. 716-728.

BORISOVA G., BROCKMAN P., JESUS M.S., ZAGORCHEV A., (2012). Government Ownership and Corporate Governance: Evidence from the EU, Journal of Banking and Finance, pp. 1-18.

BOUAISS K, (2008). Réglementation du comité de Bâle, prise de risque et performance des banques européennes. Revue Banque et Marchés, 95, pp. 6-14.

BROKOVISH K.A., BRUNARSKI K.R., CRUTCHLEY C.E SIMKINS B.J., (2004). Board Composition Corporate Use of the Interest Rate Derivatives, Journal of financial Research, 2(2), pp. 199-216. 
CAPRIO G., LAEVEN L. LEVINE R., (2007). Governance and Banks Valuations, Journal of Financial Intermediation, 16, pp. 584-617. DOI: 10.1016/j.jfi.2006.10.003

CHIA-LING HO., (2011). Board Composition, Risk Management and Corporate Performance in the Taiwanese Life Insurance Industry, Journal of Risk and Insurance, 8(4), pp. 7-27.

DAHYA, J., DIMITROV, O. MCCONNELL, J. J., (2008). Dominant shareholders, corporate boards, and corporate value: A cross-country analysis, Journal of Financial Economics, 87 (1), pp. 73-100. DOI: 10.1016/j.jfineco.2006.10.005

DAILY C.M, DALTON D.R., (1993). Board of directors Leadership and Structure: Control and Performance Implications, Entrepreneurship Theory and Practice, 17, pp. 65-81.

DANNON P.H., (2009). Mecanismes Internes de Gouvernance Bancaire et Risques Financiers dans la Zone UEMOA: uneanalyse économetrique par les données de panel, http:/ead.univ-angers.fr,pp. 1-29.

DIONNE G., TRIKI T., (2005). Risk Management and Corporate Governance: The Importance of Independence and Financial Knowledge for the Board and the Audit Committee, HEC Montreal Working Paper No. 05-03. Available at SSRN: http://ssrn.com/abstract $=730743$.

FAMA E. JENSEN M., (1983). Separation of Ownership and Control, Journal of Law and Economics, 26, pp. 301-325. DOI: $10.1086 / 467037$

HASAN, I., WACHTEL, P. ZHOU, M., (2009). Institutional development, financial deepening and economic growth: Evidence from China, Journal of Banking and Finance, 33, pp. 57-170

JENSEN M.C., MECKLING W.H., (1976). Theory of the firm: Managerial behaviour, agency costs and ownership structure, Journal of Financial Economics, 13, pp. 305-360.

JENSEN, M.C., (1993). The Modern Industrial Revolution, Exit and the Failure of Internal Control Systems, Journal of Finance, 48, pp. 831-880. DOI: $\underline{10.1111 / \mathrm{j} .1540-}$ $\underline{6261.1993 . t b 04022 . x}$

JEZZINI M., (2005).Revuedelalittérature:risqueopérationnel, http://www.ressourcesactuarielles.net, pp. 7-11.

LEFORT, F. URZÚA, F., (2008). Board independence, firm performance and ownership concentration: Evidence from Chile, Journal of Business Research, 61, pp. 615-622. DOI: 10.1016/j.jbusres.2007.06.036

LIN Y, WEN M.M YU J., (2010). Enterprise Risk Management: Strategic Antecedents, Risk Integration and Performance, SSRN, Working Paper.

LINCK, J.S, NETTER, J.M. YANG, T., (2008). The determinants of board structure, Journal of Financial Economics, 87, pp. 308-328. DOI: 10.1016/j.jfineco.2007.03.004

LIPTON M. LORSCH, J., (1992). A Modest Proposal for Improved Corporate Governance, Business Lawyer, 59, pp. 59-77.

MAMOGHLI C. DHOUIBI R., (2009). Bank Corporate Governance and Insolvency 
Risk: evidence from an emerging market, http://ssrn.com/abstract=1391878, pp. 1-28.

MANIÈRE O., (2012). The Board of directors and Banking Risk, Letter AFGE, 29, pp. 5-31.

PATHAN S., (2009). Strong Boards, CEO Power and Bank Risk-taking, Journal of Banking and Finance, pp. 1-22.

RACHDI H. GHAZOUANI B., (2011). Board Characteristics, Performance and Risktaking Behaviour in Tunisian Banks, International Journal of Business and Management, 6(6), pp. 88-97.

SALLOUM C. AZOURY N., (2008). Détresse Financière et Gouvernance d'Entreprise : Approche Empirique, Revue Libanaise de Gestionet d'Economie,1, pp. 6-43.

TRABELSI M.A., (2010). Governance and Performance of Tunisian Banks, International Journal of Economics and Finance, 2(3), pp.189-198.

TRABELSI M.A., (2011). The Impact of the Financial Crisis on the Global Economy: Can the Islamic Financial System Help?, Journal of Risk Finance, 12(1), pp. 15-25. DOI: $\underline{10.1108 / 15265941111100049}$

WILLIAMSON O., (1963). Managerial Discretion and Business Behavior, American Economic Review, 93, pp. 1032-1057.

WINTOKI M.B., LINCK J.S., NETTER J.M., (2012). Endogeneity and the dynamics of internal corporate governance, Journal of Financial Economics, 105, pp. 581-606. DOI: 10.1016/j.jfineco.2012.03.005

WURGLER J., (2000).Financial Markets and the Allocation of Capital, Journal of Financial Economics, 58, 1-2, pp. 187-214. 